\title{
Dynamic and institution in the Children of God
}

\author{
By KARIN KVIDELAND
}

Both terms in the title of this paper are so vague that it is necessary to define them more exactly and to explain how they are used here.

Dynamic is used here as an equivalent to charisma, but not however in the New Testament sense of a gift, but rather as suprahuman source of authority. A charismatic person then is someone who claims that the authority he claims is neither inherited nor given him by a group of people, but has been directly bestowed upon him by God. In other words, a charismatic person is a prophet.

Institution I shall use to describe an organisation broadly defined, containing both a social entity as the "religious system" and in the more practical aspect as the organisation of a particular movement ${ }^{1}$.

I have seen it as my purpose here to indicate the relations between dynamic and institution, between prophet and organisation within and outside the religious group "The Children of God" (COG).

It is said:

"Charismatic movements tend toward loose and informal organisation. Authority is invested in the charismatic leader as an individual, or perhaps extended to a small group of lieutenants who surround him. Any more formal organisation would rob the charismatic leader of the immediacy and the dynamic quality of his leadership."

And

"As far as we can follow the origin and development of religious groups, we can observe how they, as a rule, begin as a small group surrounding a

\footnotetext{
1 Cf. Berger 67.

2 Ib. 307.
} 
founder or leader, without any firm organisation. The group is kept together by the personality of the leader and the enthusiasm for the religious experience the members have in common. Little by little, and especially after the death of the leader, the group has to find firmer forms for its activities if it wishes to survive."3

The quotations represent a common understanding of dynamic and institution, but if we investigate a specific group with this understanding in mind, it appears to be too generalized to express the range of relations described by the terms in question.

It does not apparently take into account that the appearance of a prophet already represents one possible relation between dynamic and institution, institution in this case referring to the religious system the prophet belongs to before he received his call.

It may also be questioned whether charismatic movements do in fact tend toward loose organisation. Further it may be doubted whether a stronger organisation necessarily entails a diminution of the leader's spontaneity and a reduction of his dynamic qualities. The interaction of the personality of the leader and the enthusiasm of the members surrounding him appears to be only one of the relations between the prophet and his organisation.

Furthermore, the need for a stronger organisation may be caused by factors other than the death of the founder and leader of a particular movement.

\section{Charisma and organisation outside the COG; the appearance of a prophet}

As far as I can see we meet already here with a relation between dynamic and institution. A prophet does not arise outside an institution, they grow up in and are fostered by a particular religious system and its tradition. Otherwise there would be no prophets at all, since it is precisely their deep familiarity with this tradition that at a given moment enables them to go against it and to criticize it; a serious step which they legitimize by claiming divine calling.

Moses David, the founder, leader, and prophet of the Children of God, is no exception to this pattern. He was born into a more than usually devout

\footnotetext{
${ }^{3}$ Ringgren 122 , Translation by the author.
} 
family ${ }^{4}$; and grew up in the various denominations that his parents adhered to at different times ${ }^{5}$.

He says:

"Dedicated to the Lord and named by my mother before I was even born, I was prophesied over many times [...]" "I was an ornament in the House of God, [...] I was the Church's creation and doting son."7

But then comes a break and Moses David turns against the church. $\mathrm{He}$ begins to preach among the Hippies.

A prophet appears and tries to change his own religious system. As a consequence he is either

a) successful, or

b) unsuccessful, or

c) he accepts the status quo.

Unsuccessfulness implies two possibilities:

a) The prophet and his followers are expelled from their original religious system, they are declared to be heretics. Or

b) The prophet and his followers voluntarily leave the original religious system and form a new one. Except in modern secular societies they also leave by implication the community.

The last-mentioned possibility applies to the Children of God. Their prophet began his ministry among the Hippies in 1968, preaching that Jesus loves them, that they should find salvation if they followed Jesus and sought to forsake all. The expression "forsake all" justifies the Children's withdrawal from society, or the "system" as they prefer to call it. To begin with the group was small in numbers, but as early as 1969 the need for organisation was felt and responded to,

"[. . . ] at Laurentide [. . .] we had our first official convention and organized as a definite religious body and ordaining about 50 bishops, elders deacons, deaconesses etc. to lead the work. This was in the Fall of 1969"8.

${ }^{4}$ Cf. Brandt-Berg Virginia, 1 ff.

"Mo-letters, 1972, June 21st, § 34.

${ }^{6} \mathrm{Ib} . \S 58$.

${ }^{7}$ Mo-letters, 1972, Sept. 8th, § 121.

${ }^{8}$ Mo-letters, 1972, June 21st, § 121. 
As time went on the organizing process increased and was no longer restricted to the administration of the group, but exerted its influence over every aspect of the group's life.

When a religious group has established itself, it may either end all interaction with the surrounding community, as is the case with self-supporting monastic communities, or it may keep up a certain communication with the world. Even if the children of God claim to abandon the "system" entirely, and their message is coloured by their aversion to it, there still exists a relationship between the movement and the world. Thus the group is related to,

a) the young people among whom the Children work as missionaries,

b) older people who are willing to support the group, either by money or donations of food and clothes,

c) the authorities on whose goodwill and permission the Children depend in carrying out their ministry.

Until now I have dealt with the relation charisma/organisation preceding and leading up to the establishment of a religious group, I continue now with

\section{Charisma and organisation within the Children of God}

It has already been mentioned that a charismatic group should not be too strongly organised, since increasing organisation will necessarily cause the extinction of charisma. Instead of viewing these two phenomena as excluding each other, it is possible to understand them as steps in a continously on-going process. Inside the group too, organisation may call forth a new charisma with consequences pointed to above, the new charismatic either stays or leaves the group. The latter alternative serves as a starting point for, at least, four different ways of proceeding:

a) the Children's drop-out returns to his original religious community, or

b) he joins another already-existing religious group, or

c) he founds a new religious group, or

d) he withdraws himself either temporarily or totally from any religious commitment whatsoever.

Particularly characteristic of the Children is both their strict hierarchical 
organisation and their emphasis on the maintenance of the charismatic element.

The group is centrally administered from Dallas, Texas, USA. From this Information Center ${ }^{9}$ as it is now called, directives are issued to the bishoprics, nations, regions, districts down to the local colony, and from the colony upwards every unit is advised to place its troubles before its immediate superior instead of turning directly to Headquarters ${ }^{10}$. At the same time and often when practical advice is given, it is stressed that

"Our headquarters is in Heaven, our Leader is Jesus Christ, and our Communications is the Holy Spirit!" 11

The Heavenly Headquarters does not only communicate with Moses David; each leader of a colony may go against any advice given by the prophet, provided he is told to do so by God:

"We therefore again make this declaration of your personal independence and your right of freedom from any form of control whatsoever, either by us, your leaders, or anyone else who would try to hinder you from following your own personal leadings of the Lord!"12

From the literature of the group it appears that charismatic authority is not supposed to be restricted to the prophet and his immediate co-workers, i.e. his wife, his children and their spouses. In theory every disciple is expected to become charismatic. But since the work of the group would be slowed down or even come to a halt altogether if 4000 people (the assumed number of members) held the same authority, Moses David demands strict obedience and subordination under the leaders.

"We are to obey and submit ourselves unto those older members because God has put them over us." 13

But with the same emphasis the prophet makes it clear that every member ought to have direct connection with Heavenly Headquarters through prayer:

\footnotetext{
${ }^{9}$ Mo-letters, 1971 , July 9th, $\$ 34$.

${ }^{10}$ Mo-letters, 1971 , Oct. 1 st, $\$ 28$.

11 Ib. \& 25.

${ }^{12}$ Mo-letters, 1972, July 4 th, $\$ 4$.

${ }^{13}$ Moses 51 .
} 
"You must learn to contact his power through prayer. We must avail ourselves of God as we do of electricity." 14

Throughout his letters the prophet reminds his disciples of the importance of prayer. Sooner or later every member is supposed to receive the baptism of the Holy Spirit, to be filled with the Holy Ghost able to speak in tongues and to prophecy.

No matter what subject the prophet deals with-be it administration of the group, its economy, the training of new members, the daily life in the colonies, or the missionary work of the Children, he impresses on his followers the necessity of both charisma and organisation. Why this is so is not difficult to understand, if one knows the aim the Children have set out to achieve:

"[...] to rescue the youth of their own generation from the evils of their time: Godlessness, unbelief, confusion, paganism, drugs, violence, crime, and anarchy! [...] as well as shame, death and despair!"15

The prophet is aware that the divine call is not enough to reach this aim, charisma alone can lead to disastrous results. He is also aware that organisation alone is insufficient; it has a tendency towards perfecting itself, from being a means useful for the achievement of a particular goal, it becomes a goal in itself. As far as the Children are concerned, it is the salvation of the young generation that determines the existence and interaction of charisma and organisation.

\section{Charisma and organisation once more, outside the COG}

The Children have not been able to stop members from leaving the group. That does not mean that the relationship between charisma and organisation has come to an end. On the contrary, it may express itself in one of the four possible ways:

a) The former member of the COG returns to the religious community he previously belonged to. The charisma experienced during the stay in the group will influence the community he returns to. The backslider's rela-

\footnotetext{
${ }^{14}$ Mo-letters, 1974, June 2nd, § 50. 52.

${ }^{15}$ Mo-letters, 1972, June 21st, $\$ 5$.
} 
tionship to this community will now be different from the one he had before he joined the COG.

b) The former member of the COG joins another different but already existing religious formation; for example instead of returning to his original church he joins the Salvation Army. In this case the charisma experienced while with the COG makes itself negatively felt with regard to the community he originally belonged to.

c) The former member may repeat the role of the prophet, since he leaves the group and founds a new one. This has happened at least once in the history of the Children of God ${ }^{16}$.

d) Mention should be made of the possibility that a member of the COG leaves the group without accepting any other religious commitment. However, for the time being, I know too little to say more on this subject.

To conclude, it can be said that charisma and organisation interact with each other. Both are variables in the sense that each can be both cause and effect. Inside the Children of God both exist side by side, thus keeping the group alive. Charisma slows down the process of organisation, while the latter prevents the former from getting out of control which would obstruct instead of support the work of the group.

Two reasons for this interaction can be cited,

a) the aim of the group,

b) the coming of Christ in 1993 as preached by the Children.

The coming of Christ provides, according to the Children, yet another "transcendental" relationship between charisma and organisation: as God's co-rulers they shall then govern the universe ${ }^{17}$.

\section{Bibliography}

Berger, P. T.-Berger, Birgitte, 1972, Sociology, A Biographical Approach. N.Y. \& London. Brandt-Berg, Virginia, 1972, The Hem of His Garment. Amsterdam.

Enroth, R. M. -Ericson, E. E.-Peters, C. B., 1972, The Story of the Jesus People. Exeter. Moses, D., 1972, Revolution for Jesus. Amsterdam.

Ringgren, H., 1974, Religionens form och funktion. Lund.

${ }^{16}$ Cf. Enroth 66.

${ }^{17}$ Cf. Mo-letters, 1973, Aug. 29th, $\$ 18$. 
Mo-letters:

1971, July 9th, Personal Replies.

1971, Oct. 1st, General Letter on Various Business.

1972, June 21st.

1972, July 4th, Declaration of Independence.

1972, Sept. 8th, I'm a Toilet, are You?

1973, Aug. 29th, The Green Door.

1974, June 2nd, Sex works. 